\title{
READERS
Insight
}

Journal of Management Info (JMI)

ISSN:2313-3376

www.readersinsight.net/jmi

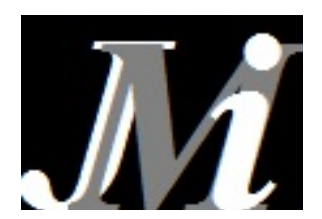

\section{The regional impacts of india-us nuclear deal}

\author{
Waseem Khan ${ }^{1 *}$, Manzoor Ahmad ${ }^{2}$, Murad Ali ${ }^{3}$ \\ ${ }^{1}$ University of Swabi \\ ${ }^{2}$ Abdul Wali Khan University, Mardan \\ ${ }^{3}$ National Defence University, Islamabad \\ * Corresponding author: waseemkhan@uoswabi.edu.pk
}

\begin{abstract}
The Indian-US nuclear deal developed a tense scenario to the strategic stability of South Asia in many ways. It intensified the already persistent political albatross between Islamabad and Delhi and Beijing and Delhi in general. The deal enables India to get access to the missile materials across the world and enrolls it into the nuclear supplier groups lopsidedly which poses much concern for Pakistan. The diplomatically biased overture of US in the wake of its nuclear whole hearted assistance to India pushed Pakistan into psychological isolation, to say the least. Given the fact that the US-India nuclear deal has a devastating regional impact, it seems as pertinent to the already existing nuclear arms race among the regional triangle; Pakistan, China and India. Both Pakistan and China showed their loathsome response to the deal and considered it as a conceived blow to the regional strategic stability, for they have longstanding territorial issues with India. Besides the strategic asymmetry that it procreates in South Asia, the deal also ensures a reassurance effect for the nuclear runner up countries like Iran and North Korea, who are in the way near to become a nuclear power state themselves. Moreover, US-India nuclear deal also proves lethal to Pakistan-US relation that focuses on the strategic stability of Afghanistan. It spawns many kinds of suspicions in Pakistan government's mind toward the US over the later impartial diplomatic approach toward the former. Pakistan in return embarks upon a cordial relation with Russia to reciprocate the US-India new engagement. Somehow it gives enough reasons for Pakistan to embolden its defense, economic and political ties with Russian and China in a bid to counterweight Indian influence in the region. The nations of both developing countries India and Pakistan are reeling under multiple problems ranging from abject poverty, poor health facilities, illiteracy, to unemployment and lack of basic life amenities. Ironically enough, the ever-gloomy picture of the people in these countries on one side and their disproportionate defense expenditures on other side forecast destructive consequences in offering as the underdeveloped society is a ticking time bomb and can be turned violently against the state. Hence, the region is in crucial need of human development in terms of education, health, economic resources, industrialization, job security and social security against all odds. The time is ripe for both India and Pakistan to draw their attention away from arms acquisition and turn towards regional multilateral engagements and learn the lesson of European countries on how they translated their once perennial rivalry into perpetual friendship.
\end{abstract}

\section{ARTICLE INFORMATION}

Received: 25 March 2018

Revised: 25 March 2018

Accepted: 25 March 2018

DOI:

http://dx.doi.org//10.31580/jmi.v12i1.63

\section{Introduction}

Obama recent visit to India on 26 Jan 2015 was seemed as a watershed in the history of India. It not only did end up in brokering nuclear deal with India by granting the latter with unprecedented concessions as nuclear commercial state, but also did visualize India an inexorably important actor for America henceforth. It is full of sanity to say that economics precedes politics, for it is economics that compelled America to get to India to pursue different kinds of bilateral engagement. The nuclear engagement between US-India dated back to the Clinton era and went through the period of Bush eras with having ups and down owing to political and legal issues. In November 2008, bush government amended the US atomic energy act 1955 (meant for disbanding the export of nuclear technology to other states) through the Hyde act 2006 exempted India from nuclear nonproliferation on priority basis. Subsequently, in 2008 the bush government secured a waiver from international atomic energy commission (IAEA) to export nuclear technology to India (Ramana, 2006). Moreover, in 2008 Indian was also awarded waiver from the nuclear supplier group in a bid to freely import nuclear technology from any country of the world. Thus, in the same year nuclear supplier group lifted the nuclear sanction against India imposed on the latter in 1978 after India tapped the Canadian uranium for military purpose.

Since 2008 foreign suppliers had been permitted to supply uranium to Indian. However, the nuclear cooperation agreement is designed to ensure that the exported nuclear material is not purportedly used for weaponry purposes, is not exported to other states, and is not reprocessed to separate plutonium without consent. In 1998, united nation Security Council resolution 1172 urged both India and Pakistan to sign up to the CTBT, stopped nuclear weapon deployment and gave up the production of nuclear bomb materials (Weiss, 2006). But utter negating with her previous stance, Obama declared equivocally Indian as a peaceful nuclear partner overlooking the fact 
that India trespassed the legal premises once in 1978. Pakistan on the other side of equation in South Asia is not only bypassed by Obama in nuclear engagement, but warned him to be scrupulous about his nuclear security. This bipartisan bilateral hookup between us and India has had far flung adverse implications on the nuclear deterrence in South Asia and Asia in general. Many analysts viewed US-India nuclear deal attached with the purpose to countervail China rising power, as India is the only nuclear state in Asia that poses threat to China because of having outstanding territorial issues between them. Pakistan looks to the US approach to India with a skeptical mind and observed vocal protest that the ulterior aims of India could be, behind the deal, vicious rather than peaceful. Sartaj Aziz said "Indo-us deal struck for political and economic expediencies but would have a detrimental impact on nuclear deterrence and overall stability in South Asia”. He argued that such a move can further compound the already fragile strategic stability in south Asia, and would further undermine the credibility of NSG, while weakening the nonproliferation regime (Weiss, 2006).

Even though the nuclear deal might bring about lethal happening to us, it portrays India as magnetic market for America through the lens of commercialism. For the last twenty five years, America had not exported nuclear material, therefore she needs a vibrant market as a good buyer. India has the world second largest population, a strong economy, huge and widespread markets and has potential to accommodate US investments at maximum level. The china factors that the deal carries set aside, its economic dimension, owning to American credit crisis, overwhelm the political dimension.

\section{Impact on non-proliferation regime}

The U.S.-Indo nuclear deal undermines the regulations set under the NPT, thereby setting ignominious precedent for the non-weapon states. It allows India to tap its entire indigenous production of uranium and a stockpile of plutonium for weapon manufactures. Moreover, the US-Indo nuclear deal weakens the NPT by degrading the commitment made by the non-weapon state to receive peaceful nuclear technology and by weakening weapon states' commitment under article one of the NPT (Weiss, 2006).

It is an utter violation of the US obligation under article one of the NPT, which aims "not to assist in any way" a non-weapon state (including India according to NPT). The nuclear deal is seemed even more preposterous for the other parties of the NPT as India under the deal is not bound to have applied IAEA full scope safeguard on their civilian facility. While the other non-weapon states are obligated to bring their peaceful nuclear activities under tight IAEA surveillance. India even opposed to placing safeguards on their breeder R\&D program and the reactor needed to produce plutonium for the breeder. It envisages the large-scale future increase in Indian weapon production capacity. India is in desperate need of nuclear deal owing to the fact that India currently lacks the uranium fuel production capacity to fulfil the weapon and civilian nuclear power goals simultaneously. Despite that India backtracked on their pledge not to make nuclear weapon after importing nuclear technology from Canada and made nuclear weapon, US while oblivious to the India vicious past, still persistently give free hand to India over nuclear material used. This blatant double standard that allows India to get away with the full scope of IAEA safeguard and still receive healthy nuclear assistance while the countries like Brazil, Japan and Germany are under the tougher standard is festering the international norms of NPT regimes.

\section{Iran factor}

The Iranian nuclear program has checkered history, taking its root in shah era of Iran when American provided nuclear assistance to Iran. US then abandoned her diplomatic relation with Iran following the religious revolution that sprouted out in Iran 1979 onward. Presently, Iran nuclear program, under the guise of civilian purpose, is under the eagle eye of the international community and is highly concerned for specially America, Israel, and Arab countries. Ever since 2004 Iran faced stringent economic and political sanctions from the US and European union for their nuclear program. Recently, Iran has drawn down on their 80 percent of uranium stockpiles and allow the remaining 20 percent material for civilian aims, through the directives of the international atomic energy agency (IAEA).

The selective aggressive stance against Iranian nuclear program stands in open contradiction to the soft corner demonstrated to the Indian nuclear program by America that perceived in US-Indo nuclear deal. Infact, the chief Iranian negotiator, Ali LARIJANI, stated, while giving reference to the US-Indo, as discriminatory act on the part of US against Iran (Aziz, 2015). Understandably, Iran knows the historical background of the Indian nuclear program and how the latter was getting ignored for its uranium enrichment program from the heavy water supplied by American and Canadian. Additionally, Indian maintained, prior to starting of the nuclear program, that its intention was purely based on civilian energy purposes strictly in the same manner as iron claimed these days against the allegations leveled by the international community. Knowing all these realities, the Indian example could be set as a precedent for Iran and could be likely recurred it in transferring its fissile material into weapons. Because the Iranian nationalists are looking for this record and concluded that they are being singled out for adverse discriminatory treatment.

\section{Nuclear deterrence in Asia}

The nuclear deterrence in Asia is strictly set among the four nuclear power states. In south Asia, the strategic stability is determined by the power equilibrium between India and Pakistan. There is nuclear power parity between the arch rival India and Pakistan, but the in the lieu of other power indicators, for instance economy, population, military power, geography and material acquisition, India dramatically outsmarts Pakistan. Nevertheless, still there is a balance of power in South Asia if the state's defense capacity solely defines it.

It has been four times until now, India and Pakistan approached each other in the battle field since 1948. The threshold of nuclear war between these two countries is quite understandable owing to the disproportionate geographical and military power of India vi's-à-via Pakistan, for the latter would likely trigger off a nuclear attack if they see their country vulnerable to the enemy. This fact has been demonstrated by the then military dictator of Pakistan general Pervaiz Musharraf in 2001-2002, amid the military standoff between India and Pakistan, that there is a thin layer laying in a nuclear war between India and Pakistan. He further added that Pakistan could launch a nuclear attack on India within eight seconds. The general asked the then communications director of tony Blair's government to remind India of Pakistan's nuclear capability. Britain was so concerned that the tony Blair's foreign policy advisor, sir David manning, categorically described in his paper that Pakistan was prepared to go to nuclear war. Indian also perceived if they cordoned off Pakistan territorially they would never stop a nuclear war in South Asia (Watt, 2012).

India is sandwiched between the two rivals; Pakistan and China. Against china, India shares the same territorial problems as with Pakistan. However, these two countries also remained Horne in lock in multi-level economics engagements. The recent visit of chines PM brought home billion of dollar deals with India, but strangely enough, both countries did not reach to settlement on their conflicting issues which may breed trouble in offing. China's assertion in Asia is perceived as an apparent threat to the offshore world power America and by applying realist policies the latter leave not a single stone unturned to tame the supremacy of the chine in Asia pacific region. China currently, sustained multiple territorial problems over the ownership of south china sea with Vietnam, Philippines, Cambodia and Laos, and over the sankako island with japan. Ever since the rise of chines territorial issues, America has drifted herself in the cohort of southeast Asian countries by giving them economic and military support at length. 
The Indo-U.S nuclear deal, is conceived by many analysts, as an overt step to countervail the assertiveness of china in the region. But it gives an impetus to the unrestrained arms competition between India and Pakistan. Obama visit to India was syncronised by the Pakistan chief of army staff general Raheel Sharif to china, giving and an apparent message about the regressive implications of US-Indo nuclear deal. This deal sets the lethal norms of arms aggrandizement particularly in south Asia and generally in Asia.

\section{Conclusion}

It is not too far away that the world will see many new international actors enrolling into a nuclear power state if the international standards of the nuclear non-proliferation treaty is the same manner ruthlessly trespassing by the actors for narrow political and economic ends. The US-Indo nuclear deal has set a devastating precedent for the non-weapon state, for they can also feel it their right to ensure their self-defense in ramping up nuclear weapons in case of a threat. Moreover, US-Indo nuclear deal goes in contrast to the principles of the comprehensive test ban treaty (CTBT), though
America has not yet ratified it, despite Obama efforts in the same direction. It is in the interest of each country to pay its due political, legal, and moral obligation to stop using nuclear stockpile for criminal use. United nations should play its literal role in implementing the binding principles of NPT across the board indiscriminately.

\section{References}

Aziz, S. (2015, January 28). Indo-US nuclear deal will disturb regional power balance: Pakistan. Retrieved March 2, 2015, from Daily Times: http://www.dailytimes.com.pk

Ramana, Z. M. (2006). Wrong Ends, Means, and Needs: Behind the U.S. Nuclear Deal with India. Arms Control Today, 11-17.

Watt, N. (2012, June 15). Pakistan boasted of nuclear strike on India within eight seconds. Retrieved March 4, 2015, from The Guardian http://www.theguardian.com/world/2012/jun/15/pakistan-boasted-nuclear-strikepakistan

Weiss, L. (2006). The Impact of the U.S.-India Deal on the Nonproliferation Regime. Washington, D.C.: Arms Control Association Press Briefing 